\title{
Information on the impact National N-Power Scheme on Employment Creation
}

\author{
Frank M. Attah ${ }^{\mathrm{a},}$, Thomas A. Omang ${ }^{\mathrm{a}}$, Mary U. Ojong-Ejoh ${ }^{\mathrm{a}} \&$ Hussein Botchway $^{\mathrm{b}}$ \\ ${ }^{a}$ Department of Sociology, University of Calabar, P.M.B. 1115, Calabar, Cross River State, Nigeria \\ ${ }^{b}$ University of Energy and Natural Resources, Ghana
}

\begin{abstract}
This study attempts to provide valuable data on the impact of the National N-Power scheme on youth employment in Bekwara Local Government Area of Cross River state. The ex post facto research design was adopted in collecting data from 398 samples from a population of 632 beneficiaries of the scheme using a self-structured questionnaire. The convenience sampling technique was used in selecting the samples from the study area. Data collected from the field was analyzed using inferential and descriptive statistics. The descriptive statistics include frequency distribution, charts, simple per centages, means and standard deviation. The result from the descriptive statistics was then subjected to parametric statistics at 0.05 confidence level. Out of the 398-instrument distributed, only 389 was returned and used for analysis. from the analysis, it was discovered that nearly all the respondents (96.92\%) were unemployed before becoming beneficiaries of the N-Power Scheme. It was also discovered that out of all the programs registered under the scheme, only three programs had beneficiaries in Bekwara, these were N-Teach, N-Agro and NHealth. From the analysis carried out using lineal regression, it was discovered that there is a significant relationship between $\mathrm{N}$ Power and Employment Creation. Based on these findings the study recommends amongst others that there is a need for an increase in the number of beneficiaries of the Scheme in the Local Government Area.
\end{abstract}

(C) 2021 Author(s). All rights reserved.

Keywords: N-Power; N-Teach; N-Agro; N-Health; Employment creation; Youth.

\section{Introduction}

The responsibility of governments globally is to provide paid employment, for her active population especially the virile and virulent youth segment of the society, remains not just a huge challenge, but also a policy issue in discourse. In Nigeria, at present and more than any other time in the history of the nation, unemployment seems to have escalated beyond manageable limit (Asaju, Arome \& Anyio, 2016). Accordingly, The National Bureau of Statistics (2019) maintains that youth unemployment stands at $36.50 \%$ as at second quarter of 2018 while the youth population within the same period stood at $42.54 \%$ with a dependency ratio of $88.2 \%$ per a 100 non dependents. Granted the current situation, it is no wonder at all, that the social crime rate in Nigeria is on the rise as evident in kidnapping, armed robbery, ritual killings, drug abuse, internet scam, Ponzi scheme, prostitution and more (Ukwayi, Angioha \& Ojong-Ejoh, 2018; Angioha, Nwagboso, Ironbar \& Ishie, 2018).

However, government awareness of the current youth unemployment in Nigeria, and the fact that successive government efforts on youth employment programs such as; the National Directorate for Employment (NDE), the National Poverty Eradication Program (NAPEP). The National Economic Empowerment and Development Strategy (NEEDS) seem to have yielded marginal result. Consequently, the present government of Buhari has evolved a new paradigm to curb unemployment and reduce social crime as well as boost economic development in the country (Eze, 2019; Okeke \& Ngonadi, 2017; Abada \& Omeh, 2019; Ojong, Iji, \& Angioha, 2019).

\footnotetext{
* Corresponding author.

E-mail address: frankmattah@unical.edu.ng (Frank M. Attah)
} 
Sequel to the above, the national social investment program (N-SIP) was heralded. (N-Power information guide 2017). Although the N-SIP bear components such as the N-Power scheme, specially crafted to carter for youth employment, there is also the N-Build, the N-tech etc. a combination of these components is expected to deliver dividend of self-employment through entrepreneurship to the various category of youths at state and local government levels, in Nigeria. In any case, Bekwara Local Governments in Cross River State happen to be one of the beneficiaries of the $\mathrm{N}$-power program, the ultimate target of the $\mathrm{N}$-power program component is to meet an average target of approximately (500.000.000) five million unemployed youths across the states and local government areas through randomization of the beneficiaries who eventually are trained and empowered for self-actualization. N-Power information guide (2017).

According to National Bureau of Statistics (2018), the N-power assessment report revealed that in 2017, 200.000 youths were engaged in the n-power scheme, and it crashed youth unemployment from 23.6 per cent to 16.6 per cent and in 2018 another 300,000 was engaged thus further reducing unemployment from 32.45 to 29 -.75 per cent (National Bureau of Statistics, 2019). Akujuru \& Enyoko (2019) corroborating this assertion states that beyond the Npower benefits, youths also have the N-build and N-tech of the N-SIP program to enhance their capacities. Furthermore, the implication of the report of the $(500,000)$ five hundred thousand beneficiaries of the $\mathrm{N}$-power is hat youths from Bekwara Local Government are integral parts of the stock of beneficiaries and therefore characteristics of delinquency and other social ills among the Bekwara youths should be reasonably in check or greatly reduced.

However, a study on youth restiveness and cult activities in the Northern Senatorial District of Cross River State, where Bekwara Local Government Area is located revealed that the northern youths are still highly akin to restiveness due to correlating factors such as poverty, idleness lack of active engagement in entrepreneurial activities. judging from the above, it remains to prove whether the N-power pilot program in Bekwara Local Government Area has significantly impacted the youths and fulfilled the obligation for its establishment or it is a fluke and political rhetoric with government circle, as usual. Conclusively, the study shall draw purposively from a sample of supposed beneficiary to test the impact of the n-power social intervention scheme using appropriate instrument to actualize the result.

\section{Literature Review}

\subsection{Social intervention scheme in Nigeria}

Social intervention scheme are programs conceived with the aim of safeguarding and supporting the vulnerable in the society such as unemployment, women, children, the disabled, displace and the employed. They are programs or enterprise created to deliver socio-economic benefits and develop the human capital potentials of specific groups. Social intervention schemes take the form of social welfare packages, social protection and safety net such as poverty reduction programs, access to healthcare pension and insurance schemes, access to health care services etc. (Abada \& Omeh, 2019; Okeke \& Ngonadi, 2017; Eze, 2019; Ndem, Angioha, \& Dike, 2020). Social intervention schemes are funded and implemented by both government and/or its agencies, international agencies and private sector entities. In Nigeria, social intervention schemes are not new, nearly all the government that ruled the nation have implemented one scheme or the other (Okonkwo, 2015). Almost all these schemes have been short termed and small scaled. These schemes base on empirical evidence recorded some form of success. For example, the sure-p scheme successfully deployed 119,000 beneficiaries to different vocational skills program addressing the issue of unemployment by Mid 2013 (sure-p final draft, 2014). The material and new-born child health program (M NCHJ) recorded over 1.4 million safe and healthy births.

\subsection{Employment situation and the Creation of N-Power}

The Nigeria economy have recovered impressively and growing after the 2016 economic recession, but one problem that the government has failed to find a solution to is unemployment (Onoyabe, 2019). The World Bank (2019) report that out of the 5 million Nigerian graduates that enter the labour market 2018, only 450,000 are currently employed. The Nigerian economic update (2019) in its figure of 2019, maintained that unemployment stood at 23 per cent. this figure is supported by the National Bureau of Statistics (2019) in its 2019 report maintain that unemployment rate for the third quarter of 2019 stood at 23.1 per cent. The report holds that out of the 20.9 million Nigerians that were 
unemployed as at the third quarter of 2018, 11.1 million were under underemployed this figure supported other evidence that unemployment is at its highest ratio in the history of the nation. In the country's banking sector, on the average, up to 18 bankers lost their job everyday between January and September 2019 (Andrew, 2019). As if the situation is not bad enough, it is projected that the unemployment rate is expected to grow to 33.5 per cent by the year 2020 (Central Bank of Nigeria, 2017). The rate of unemployment has had a concomitant effect on the country's development.

In reaction to the continuing growth of poverty and unemployment the federal government under the National Social Investment Scheme (N-Sip), introduce the N-power program with the specific objective of youth empowerment and job creation in Nigeria (N-power information guide, 2017). The program was specifically designed to help Nigerian youth develop and acquire practical skills that will allow them to make meaningful impact in their community as well as become innovative players in both global and domestic market (N-power information guide, 2017). The graduate program is further divided into $\mathrm{N}$-agro, $\mathrm{N}$-health, $\mathrm{N}$-teach and $\mathrm{N}$-tax. The graduate program deployed 500,000 graduates to support specific identified sectors of the Nigerian economic. The graduate are deployed and paid 30,000 naira monthly with various devices that will help them carryout the task in the sphere of activity. The non-graduate program is aimed at preparing young Nigerian youth wit knowledge that will equip them with world class skills and certification (N-power information guide, 2017).

\subsection{Review of empirical literature}

Review of literature revealed empirical evidence of the impact of the correlates of $\mathrm{N}$-power program and employment creation. Eze (2019) in his work argued that the social intervention schemes introduced by the Buhari and Jonathan administration reduce the country's unemployment problem to its barest minimum. Abada and Omeh (2019) examined social intervention scheme in Nigeria and poverty alleviation. utilizing quantitative method for data collection, found that government social intervention scheme had helped to alleviate poverty among the youth. Bisong (2019) the impact of N-power scheme on employment creation, job skill enhancement and the economic wellbeing of the beneficiaries in southern sensational distract of cross river state. The survey research was used to collect data for a sample of two hundred and fifty using structured questionnaire collected data was analyzed using Pearson product moment correlation. Results revealed that a significant relationship exist between the N-power and employment creation, job still enhancement and economic wellbeing Odey and Sambe (2019) examined the impact of N-power on youth empowerment in Cross River State, Nigeria adopting the gross section design, 167 beneficiaries were selected using the cluster random sampling technique. The instrument of data collection was the questionnaire and key information interview. Results revealed that the N-power scheme significantly contribute to poverty reduction, financial empowerment and skill development

\section{Methods}

\subsection{Study Area}

Bekwara is a Local government Area in Cross River state, was created out of the old Ogoja Local Government Area by the General Abacha military administration in 1996. With its headquarters at Abuochechie, it is divided into 11 Local Government Ward, with two major ethnic group making up 70 per cent of the population of the area (Bekwara and Afreke) (Abua, Ajake \& Okpilia, 2013; Omagu, 1997). Bekwara has a landmass of 345 square kilometer and shares boundary with Yala Local Government Area to the West, Obudu Local Government Area to the East, Ogoja to the South and Benue State to the North. Bekwara local government has sixteen clans. The major occupational activity of the area is farming with a minority been civil servant. Bekwara has a rich cultural heritage, with the popular Ipam Ihihe (New Yam Festival) been held yearly. The National Population Commission (2006) estimates the population of the area to be 105,852 . The youth ages between 15 and 39 make up 67 per cent of the population (City population, 2018). As a result of lack of industries in the area, one problem that the local government faces is unemployment.

\subsection{Research Design}

The study adopts the Ex post Facto research method for the process of data collection, the method is a research method that allows the researcher to study a group with qualities that are already in existence with other variables. Ex 
Post fact research method does not allow the researcher control over the variables under study. adopting the Ex Post facto research design, the Self-administered structured questionnaire was used to collect data for the study. the questionnaire was designed in a Likert scale format designed to accommodate the objective of the study.

\subsection{Sampling}

The population comprised of youths aged 18 and above from Bekwara Local Government Area who are beneficiaries of the N-power program. Information gathered from the office coordinating the N-power program in cross river state, the beneficiaries stand at 632 . the sampling size used for the study was 398, arrived at using the survey monkey sampling determinant technique at a confidence level of $95 \%$ and a margin of error of 3 per cent. The snow ball sampling technique was used to select the samples needed from the effect of the $\mathrm{N}$-power, the researchers were able to get the names and numbers of 2 beneficiaries, these beneficiaries were located and gave the researcher direction on how to find other beneficiaries.

\subsection{Method of Data Analysis}

Data collected from the field was analyzed using inferential and descriptive statistics. The descriptive statistics includes frequency distribution, charts, simple per centages, means and standard deviation. The result from the descriptive statistics was then subjected to parametric statistics at 0.05 confidence level.

\section{Results}

\subsection{Descriptive statistics}

The aim of the study was turn to questions used to collect data from the samples of the study. the collected data was subjected to descriptive statistics.

Table 1. Response on N-Power and Employment Creation

\begin{tabular}{lllll}
\hline S/N & Question & N-Teach & N-Agro & N-Health \\
\hline 1 & Which of the N-Power program are you a beneficiary & $347(89.20)$ & $11(2.83)$ & $31(7.97)$ \\
\hline
\end{tabular}

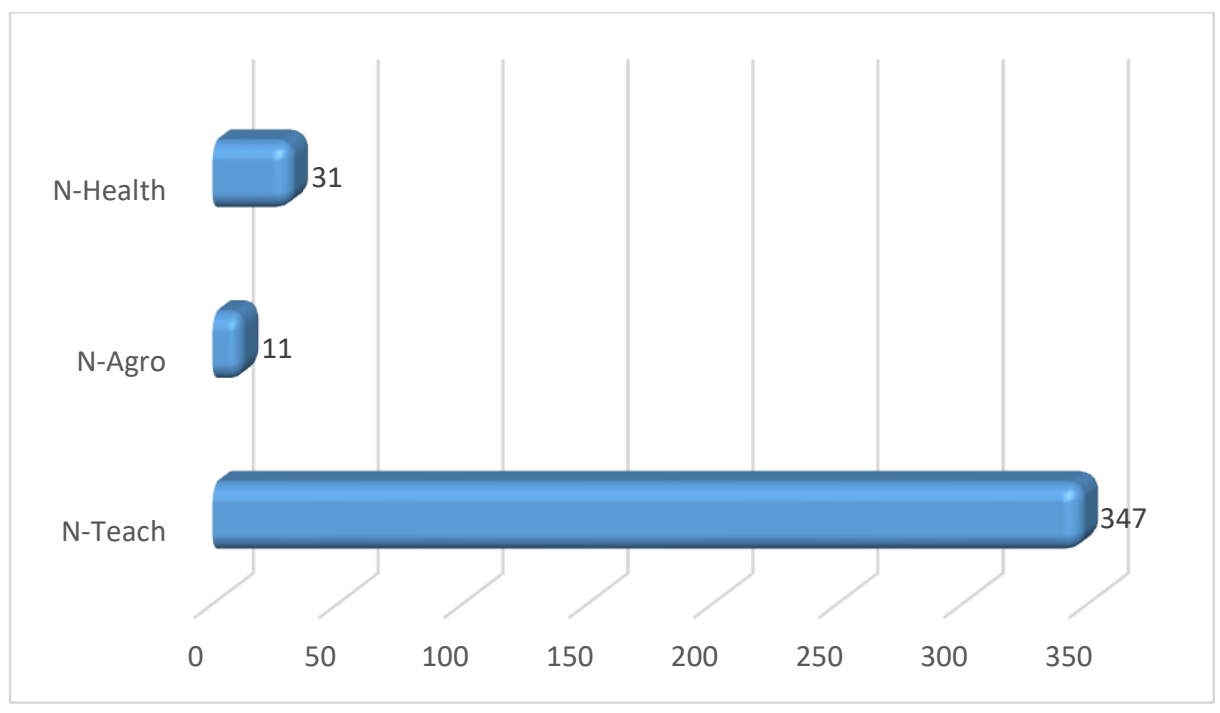

Fig. 1. Response on N-Power and Employment Creation 
Table 2. Response on N-Power and Employment Creation

\begin{tabular}{|c|c|c|c|c|}
\hline $\mathrm{S} / \mathrm{N}$ & Question & Yes & No & Not Sure \\
\hline 2 & $\begin{array}{l}\text { I now earn a living as a beneficiary of the N-Power } \\
\text { program }\end{array}$ & $389(100.00)$ & 0 & 0 \\
\hline 3 & Before becoming a beneficiary, I was unemployed & $12(3.08)$ & 377 (96.92) & 0 \\
\hline 4 & $\begin{array}{l}\text { The money I earn from the N-Power program is enough } \\
\text { to take care of me }\end{array}$ & $17(4.37)$ & $368(94.60)$ & $4(1.03)$ \\
\hline 5 & $\begin{array}{l}\text { There is need for government to improve or increase } \\
\text { beneficiary's take home package }\end{array}$ & 379 (97.43) & $10(2.57)$ & 0 \\
\hline 6 & Working conditions are conducive & $112(28.79)$ & $277(71.21)$ & 0 \\
\hline 7 & $\begin{array}{l}\text { There is need for the number of beneficiaries to be } \\
\text { increased. }\end{array}$ & $389(100.00)$ & 0 & 0 \\
\hline
\end{tabular}

There is need for the number of beneficiaries to be increased.

Working conditions are conducive

There is need for government to improve or increase beneficiary's take home package

The money I earn from the N-Power program is enough to take care of me

Before becoming a beneficiary, I was unemployed

I now earn a living as a beneficiary of the N-Power program

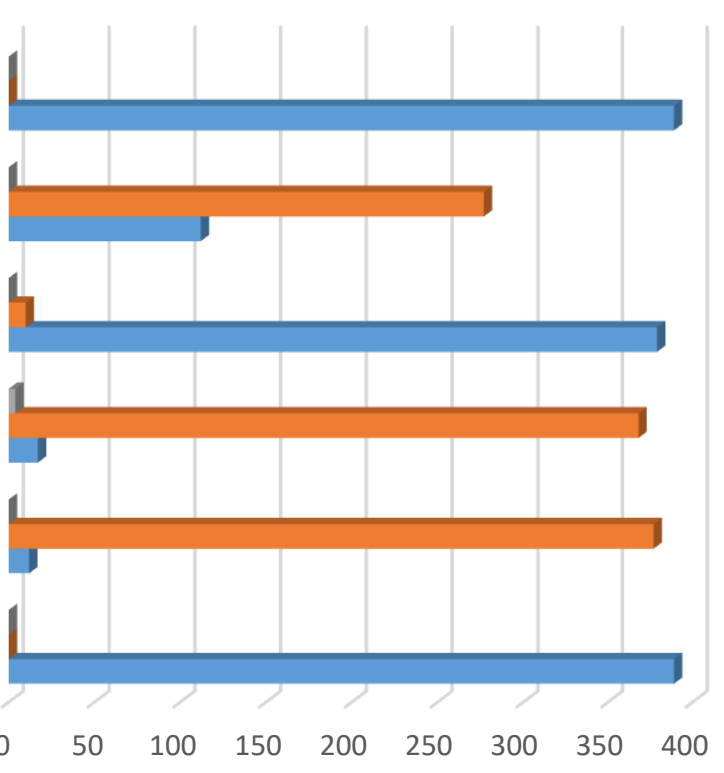

$\square$ Not Sure $\square$ No $\quad$ Yes

Fig. 2. Response on N-Power and Employment Creation

Result from the descriptive analysis revealed thus; most of the respondents, 347, representing 89.20 per cent were beneficiaries of $\mathrm{N}$-Teach, 11 respondents, representing 2.83 per cent were beneficiaries of N-Agro and 31 respondents representing 7.97 were beneficiaries of N-Health. On I now earn a living as a beneficiary of the N-Power program; all the respondents 389 representing 100.00 per cent reported yes. On Before becoming a beneficiary, I was unemployed; 12 respondents representing 3.08 per cent reported Yes, 377 respondents representing 96.92 per cent reported No. On The money I earn from the N-Power program is enough to take care of me; 17 respondents representing 4.37 reported Yes, 368 respondents representing 94.60 per cent reported No and 4 respondents representing 1.03 per cent reported Not sure. There is need for government to improve or increase beneficiary's take home package; 379 respondents representing 97.43 reported Yes, 10 respondents representing 2.57 per cent reported No. On Working conditions are conducive; 112 respondents representing 28.79 per cent reported Yes, 277 respondents representing 71.21 per cent reported No. On There is need for the number of beneficiaries to be increased; All respondents 100.00 per cent reported Yes. 


\subsection{Regression Analysis}

The result from the descriptive analysis was subjected to simple regression analysis at 0.05 confidence level. Result is presented in table 3. The independent variable is $\mathrm{N}$-power and dependent variable is Employment creation

Table 3. Summary simple linear regression analysis of relationship between N-Power and Employment Creation

\begin{tabular}{lll}
\hline Variables & Mean & Std. Deviation \\
\hline Mass transit & 14.3425 & 3.20247 \\
Scio economic wellbeing & 44.6650 & 9.70455 \\
\hline
\end{tabular}

\begin{tabular}{lccccccc}
\hline \multicolumn{1}{c}{ Model } & Sum of Squares & Df & F & R & R Square & $\begin{array}{c}\text { Adjusted R } \\
\text { Square }\end{array}$ & Sig \\
\hline Regression & 1184.812 & 1 & 12.958 & $0.178^{\mathrm{a}}$ & 0.032 & 0.029 & $0.000^{*}$ \\
Residual & 36392.298 & 398 & & & & & \\
Total & 37577.110 & 399 & & & & & \\
\hline
\end{tabular}

The result of analysis as presented in table 3 revealed that the $\mathrm{R}$-value of .178 is significant at 0.05 alpha level (p-value of .000 is less than 0.05). This implies that there is a significant relationship between N-Power and Employment Creation. Also, the $\mathrm{R}^{2}$-value of 0.32 implies that only $32 \%$ of total variance is accounted for by predictor variable $(\mathrm{N}-$ Power). Furthermore, the regression ANOVA revealed that, there was a moderate joint linear association (contribution) of the predictor variables (N-Power) on employment creation given by the F-ratio $(1,398)=12.958 ; \mathrm{p}$ $<0.05$. The adjusted $R^{2}(.029)$ shows some shrinkage of the unadjusted value (.032) indicating that the model could be generalized on the population. Based on the result, it was concluded that the N-Power programme has significantly created employment for youths in Bekwara Local Government Area of Cross River State, Nigeria.

\subsection{Discussion of Findings}

Result gathered from the field revealed that from the N-Power scheme, N-Teach is the most popular, with 89.20 per cent of all the respondents engaged in the Teachers program. This sis followed by N-Health, which had 7.97 per cent of the scheme beneficiaries and then N-Agro, which had just 2.83 per cent of the beneficiaries in Bekwara. There were no beneficiaries of other N-Power schemes in Bekwara. From the result analyzed it was discovered that nearly all the respondents $(96.92 \%)$ were unemployed before becoming beneficiaries of the N-Power Scheme. This implies that most of the beneficiaries of the scheme joined the program as a result of being unemployed. But a large majority of the beneficiaries, 94.60 per cent, point out that the take-home package they receive for the scheme is too small and call for improvement in the benefits.

From the analysis carried out using lineal regression, it was discovered that there is a significant relationship between $\mathrm{N}$-Power and Employment Creation. This is because, the R-value of .178 is significant at 0.05 alpha level (p-value of .000 is less than 0.05 . Also, the $\mathrm{R}^{2}$-value of 0.32 implies that only $32 \%$ of total variance is accounted for by predictor variable (N-Power). Furthermore, the regression ANOVA revealed that, there was a moderate joint linear association (contribution) of the predictor variables (N-Power) on employment creation given by the F-ratio $(1,398)=12.958 ; \mathrm{p}$ $<0.05$. Based on the result, it was concluded that the N-Power programme has significantly created employment for youths in Bekwara Local Government Area of Cross River State, Nigeria. This finding is similar to that of Bisong (2019), whose study on the impact of N-power scheme on employment creation, job skill enhancement and the economic wellbeing of the beneficiaries in southern sensational distract of cross river state found a significant relationship between the N-power and employment creation, job still enhancement and economic wellbeing. The study of Odey and Sambe (2019) examined the impact of N-power on youth empowerment in Cross River State, Nigeria found that the N-power scheme significantly contribute to poverty reduction, financial empowerment and skill development. 


\section{Conclusion and Recommendation}

The study has provided reliable data on the impact the National N-Power program has had on youth employment in Bekwara. Based on this finding, the study calls for an improvement in the number of beneficiaries of the Scheme in the Local Government Area. The government also need to create an enabling environment that will encourage private investments in the scheme, since the government cannot bear the unemployment burden of Bekwara and other locality in Nigeria alone. There is also the need to improve the take home package of beneficiaries.

\section{References}

Abada, I. M. \& Omeh, P. H. (2019). Social Intervention Schemes and Poverty Alleviation Among Nigerian Youths; International Journal of Scientific and Research Publications (IJSRP) 9(9), 2-7

Akujuru, C. A. \& Enyioko, N. C. (2019). The Impact Of N-Power Programmes On Poverty Alleviation in Nigeria: A Study Of Rivers State. Global Journal of Political Science and Administration Vol.7, No.3, pp.29-50

Angioha, P. U., Nwagboso, S. N., Ironbar, A. E. \& Ishie, E. U. (2018). Underemployment: A Sociological and Policy Analysis of Workers WellBeing in Hospitality Industry in Calabar, Cross River State, Nigeria. IOSR Journal of Humanities and Social Science (IOSR-JHSS), 13 (6), 57-66

Asaju, K., Arome, S. \& Anyio, F.S. (2014). "The Rising Rate of Unemployment in Nigeria: theSocio-economic and Political Implications." Global Business and Economics Research Journal, 3(2): 12-32

Bisong, D. B. (2019). Impact Assessment of the N-power Scheme: A Study of Southern Senatorial District of Cross River State. Journal of Public Administration and Social Welfa Research 4 (1), 31-38

Eze, K. T. (2019). Government Social Intervention and Job Creation in Nigeria: A Study of SURE-P and N-POWER Programmes, 2012- 2018. Global Journal of Human-Social Science: H Interdisciplinary. 19 (7), 40-50.

National Bureau of Statistics (2017). Nigerian Gross Domestic Product Report (Expenditure and Income Approach) (Q3-Q4 2016) https://www.nigerianstat.gov.ng/

National Bureau of Statistics (2018). Under-employment/Employment Report: Q4 2016: Abuja: Proshare

National Population Commission (2006). Population Census for 2006 Nigeria Demographic and Health Survey. Abuja, Nigeria

NBS (2018) Labor Force Statistics: Volume 1 Abuja: National Bureau of Statistics (NBS)

Ndem, M. A., Angioha, P. U. \& Dike, E. (2020). Improving the Socio-Economic Wellbeing of Rural People: Analysis of the Impact of the Community and Social Development Project (CSDP) tn Odukpani Local Government Area of Cross River State, Nigeria. Asian Journal of Applied Sciences.8 (2), 88-94.

N-Power (2017). N-Power Information Guide: Federal Government of Nigeria, National Social Investment Programme

Ochiche, C.A., Ajake, A.O.\& Okpilia, F.I. (2013). Spatio-Temporal Distribution of Rural Marketin Bekwarra local Government Area of Cross River State of Nigeria. Journal of Humanities and Science. 16(3), 104-112

Odey, S. A \& Sambe, N. (2019). Assessment of the contribution of N-Power Programme to Youth Empowerment in Cross River State, Nigeria. International Journal of Sociology and Anthropology Research, 5(4),1-13.

Ojong, M. U., Iji, M. E., Angioha, P.U. (2019). Curing Socio-Economic ILLS in Obudu Local Government Area: An Assessment of Non-Governmental Agencies Activities". Journal of Social Service and Welfare;1(2): 38-45.

Okeke, C. \& Ngonadi, A (2017) "The Politics of Subsidy Reinvestment and Empowerment Programme (SURE-P) and Youth Employment in Nigeria". NG Journal of Social Development. 6(2). 10-30 
Olajide and Diah (2017). N-power progamme and Nigerian poverty indices, matter arising. International Journal of Sociology and Anthropology Research, 5(4), 1-13.

Omagu, D. D., (1997). History of Bekwarra people of the upper. Cross River, Calabar, Achu Publisher,

Ukwayi, J. K., Angioha, P. U. \& Ojong-Ejoh, M. U. (2018). Youth empowerment: A criminological approach for crime prevention and control in Cross River State, Nigeria. IOSR Journal of Humanities and Social Science (IOSR-JHSS), 22 (11), 73-81. 